\title{
PENERAPAN MODEL PEMBELAJARAN BERBASIS MASALAH (PBM) UNTUK MENINGKATKAN KEMAMPUAN PEMAHAMAN KONSEP MATEMATIKA PADA MATERI PECAHAN SISWA KELAS VII DI SMP SWASTA ISTIQLAL DELI TUA
}

\author{
Yuli Ragelia Sinaga \\ Peodi Pendidikan Matematika FMIPA Unimed \\ email: yuliragelia@gmail.com \\ Nurliani Manurung \\ Dosen Matematika FMIPA Unimed \\ email: nurlianimanurung@yahoo.co.id
}

\begin{abstract}
ABSTRAK
Penelitian ini bertujuan untuk mengetahui peningkatan pemahaman konsep siswa setelah penerapan model Pembelajaran Berbasis Masalah (PBM) pada materi pecahan kelas VII di SMP Swasta Istiqlal Delitua Tahun Ajaran 2014/2015. Jenis penelitian ini adalah penelitian tindakan kelas (classroom action research). Subjek dalam penelitian ini adalah kelas VII di SMP Swasta Istiqlal Delitua dengan jumlah siswa 33 orang dan objek dalam penelitian ini adalah meningkatkan pemahaman konsep siswa dengan penerapan model Pembelajaran Berbasis Masalah (PBM) pada materi pecahan kelas VII di SMP Swasta Istiqlal Delitua tahun ajaran 2014/2015. Instrumen penelitian ini terdiri dari tes dan observasi. Penelitian terdiri 2 siklus dan tes diberikan pada setiap akhir siklus. Hasil tes pemahaman konsep matematika siklus I nilai rata-rata 63,85 dan klasikal kategori "baik" 57,57\%. Siklus II nilai rata-rata adalah 81,69 dan secara klasikal kategori "sangat baik" 90,90\%. Hasil observasi kemampuan guru menelola pembelajaran siklus I rata-rata 3,15 dengan kategori "baik", siklus II berkategori "sangat baik" nilai ratarata 3,5. Kesimpulan penelitian yaitu penerapan model pembelajaran berbasis masalah dapat meningkatkan pemahaman konsep matematika siswa.
\end{abstract}

\section{ABSTRACT}

This study was aimed to know the students increased understanding of the concept after the application of problem based learning model of class VII SMP Swasta Istiqlal Delitua of the school year 2014/2015. Research-shaped Classroom Action Research. Research subjects VII grade students in SMP Swasta Istiqlal Delitua consisted of 33 peoples and the object of research is applying measures problem-based learning model to increased understanding of the concept of class VII SMP Swasta Istiqlal Delitua of the school year 2014/2015. Study data obtained from tests and observation sheets. The study comprised two cycles and the test given at the end of each cycle. Test results understanding of math concept I cycle the average value of 63,85 and in the classical category of "good" 57,57\%. Cycle II, the average value is 81,69 and in the classical category of "very good" $90,90 \%$. Observations of teachers ability to manage the learning I cycle an average of 3,15 with the category of "good", cycle II categorized "very good"

Yuli Ragelia Sinaga, Nurliani Manurung, 2015. Penerapan Model Pembelajaran Berbasis Masalah (PBM) untuk Meningkatkan Kemampuan Pemahaman Konsep Matematika pada Materi Pecahan Siswa Kelas VII. Inspiratif. Vol. 1 No. 1, hal 75-82 
average value of 3,5. Conclusion of the study is the application of problem-based learning model can enhance students 'understanding of mathematical concepts.

\section{Keywords : Model, Problem-based learning (PBL), ability to understanding, concept of Mathematics}

\section{PENDAHULUAN}

Perkembangan Ilmu pengetahuan dan Teknolohi (IPTEK) saat ini sangat pesat sehingga informasi yang terjadi di dunia dapat diketahui segera dan waktu serta batas Negara sudah tidak ada perbedaan lagi, akibatnya lahirlah masa atau era yang dikenal dengan globalisasi. Untuk itu diperlukan sumber daya manusia yang handal dan mampu berkompetisi secara global. Untuk mencapai tujuan tersebut tentu saja diperoleh dengan suatu proses pendidikan yang berkualitas.

Salah satu mata pelajaran yang merefleksikan tujuan tersebut adalah matematika. Matematika adalah suatu alat untuk mengembangkan cara berpikir. Karena itu matematika sangat diperlukan baik untuk kehidupan sehari-hari maupun dalam menghadapi kemajuan IPTEK sehingga matematika perlu dibekalkan kepada setiap peserta didik sejak SD, bahkan TK. Hudojo (2005: 37).

PERMENDIKNAS No.22 Tahun

2006 menyebutkan, mata pelajaran matematika bertujuan agar peserta didik memiliki kemampuan sebagai berikut: (1) memahami konsep matematika, menjelaskan keterkaitan antar konsep dan mengaplikasikan konsep atau algoritma secara luwes, akurat, efisien, dan tepat dalam pemecahan masalah; (2) menggunakan penalaran pada pola sifat, melakukan manipulasi matematika dalam membuat generalisasi, menyususn bukti atau menjelaskan gagasan dan pernyataan matematika; (3) memecahkan masalah yang meliputi kemampuan memahami masalah, merancang model matematika, menyelesaikan model dan menafsirkan solusi yang diperoleh; (4) mengkomunikasikan gagasan dengan symbol, tabel, diagram, atau media lain untuk memperjelas keadaan atau masalah; (5) memiliki sikap menghargai kegunaan matematika dalam kehidupan, yaitu memiliki rasa ingin tahu, perhatian, dan minat dalam mempelajarai matematika

serta sikap ulet dan percaya diri dalam pemecahan masalah. Dari tujuan pembelajaran matematika, kemampuan pemahaman konsep adalah salah satu kemampuan yang harus dikuasai oleh siswa.

Muijs dan Reynolds (2008: 342) menjelaskan bahwa contoh-contoh yang diberikan guru harus sedekat mungkin dengan dunia nyata, dan konsep-konsep matematika baru harus dijelaskan dengan menggunakan beragam representasi, misalnya representasi simbolik, representasi grafik, representasi melalui penggunaan berbagai macam bahan, dan lain-lain. Dengan cara ini murid dapat belajar memikirkan tentang konsep matematika terlepas dari representasi fisiknya.

Dari penjelasan ini sudah menjadi keharusan bagi setiap guru untuk menitikberatkan pengajaran matematika pada masalah keseharian siswa agar mampu melakukan translasi dan membentuk pengetahuan awal atau konsep baru dalam struktur kognitif siswa, konsep-konsep tersebut dibahas dan sedapat mungkin melatih siswa untuk membangun sendiri konsep dari masalah yang ada. Salah satu upaya yang dapat dilakukan untuk mengatasi masalah-masalah tersebut adalah dengan menerapkan model pembelajaran berbasis masalah (PBM).

Pembelajaran berbasis masalah merupakan salah satu model pembelajaran inovatif yang member kondisi belajar aktif 
kepada peserta didik dalam kondisi dunia nyata. (Yamin, 2013: 62)

Berdasarkan penjelasan di atas, penulis tertarik untuk melakukan penelitian yang berjudul "Penerapan Model Pembelajaran Berbasis Masalah (PBM) untuk Meningkatkan Kemampuan Pemahaman Konsep Matematika pada Materi Bangun Datar Siswa Kelas VII di SMP Swasta Pelita Medan T.A 2013/2014"

Adapun tujuan penelitian ini adalah untuk mengetahui peningkatan pemahaman konsep siswa kelas VII SMP Swasta Istiqlal Delitua tahun ajaran 2014/2015 setelah penerapan model pembelajaran berbasis masalah pada pokok bahasan Pecahan.

\section{METODE PENELITIAN}

\section{Lokasi dan Waktu Penelitian}

Penelitian ini dilakukan di SMP

Swasta Istiqlal Delitua yang beralamat di Jln. Stasiun No.1A Suka Makmur Delitua Deli serdang dan pelaksanaanya pada semester I Tahun Ajaran 2014/2015.

\section{Subjek dan Objek Penelitian}

Subjek dalam penelitian ini adalah siswa kelas VII SMP Swasta Istiqlal Delitua Tahun Ajaran 2014/2015. Sampel yang akan diambil dalam penelitian ini adalah kelas VII-3 berjumlah 33 siswa. Objek dari penelitian ini adalah Penerapan Model Pembelajaran Berbasis Masalah (PBM) untuk Meningkatkan Kemampuan Pemahaman Konsep Matematika pada Materi Pecahan Siswa Kelas VII di SMP Swasta Istiqlal Delitua T.A 2014/2015.

\section{Jenis Penelitian}

Jenis penelitian yang digunakan dalam penelitian ini adalah Penelitian Tindakan Kelas (Classroom Action Research). Arikunto (2008: 3) menyatakan bahwa penelitian tindakan kelas merupakan suatu pencermatan terhadap kegiatan belajar berupa sbuah tindakan, yang sengaja dimunculkan dan terjadi dalam sebuah kelas secara bersama. Dalam melaksanakan suatu penelitian tindakan kelas, seorang guru terlebih dahulu harus mampu memahami persoalan-persoalan apa yang dihadapinya sehari-hari di ruang kelas, sewaktu kegiatan belajar mengajar. Penghayatan terhadap persoalan-persoalan tersebut harus mampu mendorongnya untuk melakukan pemecahan masalah sehingga dapat diwujudkan berbagai bentuk peningkatan atau perbaikan dalam kegiatan belajar mengajar (Maryunis 2003: 115). Dengan demikian dapat disimpulkan bahwa penelitian tindakan kelas adalah usaha yang dilakukan oleh guru untuk memperbaiki dan meningkatkan kualitas pembelajaran dengan melakukan perubahan-perubahan secara terencana.

\section{Prosedur Penelitian}

Sesuai dengan jenis penelitian ini yaitu penelitian tindakan kelas maka penelitian ini memiliki beberapa tahap yang merupakan suatu siklus. Tiap siklus dilaksanakan sesuai dengan perubahan yang akan dicapai. Pada penelitian ini jika siklus pertama tidak berhasil yaitu proses belajar mengajar belum meningkatkan kemampuan pemahaman konsep siswa yang dilihat dari hasil tes kemampuan pemahaman konsep akan diadakan beberapa siklus sampai peningkatan tercapai. Pada penelitian ini kriteria tercapainya penelitian adalah adanya peningkatan kemampuan pemahaman konsep siswa yang dilihat dari nilai rata-rata kemampuan pemahaman konsep siswa pada siklus I < nilai rata-rata kemampuan pemahaman konsep siswa pada siklus II, dan hasil belajar siswa dilihat dari persentase siswa yang mencapai KKM pada siklus I $<$ persentase siswa yang mencapai KKM pada siklus II, dan menunjukkan bahwa $\geq 75 \%$ dari jumlah siswa yang mengikuti tes telah mencapai KKM atau ketuntasan individual. Senada dengan pernyataan Bloom (dalam Winkel 2007: 466) bahwa syarat ketuntasan belajar secara individual adalah apabila $75 \%$ peserta didik mencapai KKM.

Yuli Ragelia Sinaga, Nurliani Manurung, 2015. Penerapan Model Pembelajaran Berbasis Masalah (PBM) untuk Meningkatkan Kemampuan Pemahaman Konsep Matematika pada Materi Pecahan Siswa Kelas VII. Inspiratif. Vol. 1 No. 1, hal 75-82 
Mekanisme pelaksanaan penelitian tindakan kelas pada penelitian ini, didasarkan pada prosedur pelaksanaan yang dikemukakan oleh Kemmis dan Mc Taggart. Prosedur yang dilaksanakan terdiri dari empat tahap untuk satu siklus yaitu: (1) penyusunan rencana, (2) tindakan, (3) observasi, dan (4) refleksi. Suatu siklus dalam penelitian tindakan kelas tidak dapat ditentukan terlebih dahulu jumlahnya, berhasil atau tidaknya suatu penelitian dilihat dari ketepatan tindakan yang diberikan. Mengingat perencanaan perangkat pembelajaran dan instrumen tes membutuhkan waktu yang lama, sedangkan jadwal penelitian harus disesuaikan dengan jadwal sekolah, maka peneliti merencanakan perangkat pembelajaran dan instrument tes untuk 2 (dua) siklus.

\section{Alat Pengumpul Data}

Tes

Tes pemahaman konsep yang digunakan adalah berbentuk esai yang bertujuan untuk mengetahui kemampuan pemahaman konsep siswa terhadap materi yang diberikan. Tes pemahaman konsep terdiri dari soal yang berisi tentang mencari luas pecahan. Dari tes pemahaman konsep siswa diketahui pemahaman konsep siswa sebelum dan sesudah diterapkan pembelajaran berbasis masalah (PBM).

Ada beberapa hal yang perlu diperhatikan oleh peneliti sebelum menyusun tes, diantaranya adalah:

1. Menentukan ruang lingkup pertanyaan.

2. Menentukan apa yang diukur meliputi aspek kognitifnya, yaitu pengetahuan $\left(\mathrm{C}_{1}\right)$, pemahaman $\left(\mathrm{C}_{2}\right)$, dan penerapan $\left(\mathrm{C}_{3}\right)$.

3. Menyusun kisi-kisi tes, dalam kisi-kisi tes tampak ruang lingkup materi yang diujikan, bentuk soal dan jumlah soal.

4. Menyusun soal berdasarkan kisikisi yang telah dibuat.

5. Membuat penyelesaian soal
Observasi yang dilakukan ada dua jenis yaitu observasi terhadap peneliti dan siswa. Observasi dilakukan secara bersamaan pada saat pelaksanaan tindakan pembelajaran. Dalam hal ini guru bidang studi matematika bertindak sebagai salah satu pengamat (observer) yang bertugas untuk mengobservasi peneliti (yang bertindak sebagai guru) selama kegiatan pembelajaran. Observasi ini dilakukan untuk mengetahui sejauh mana pelaksanaan pembelajaran matematika dengan menggunakan pembelajaran kontekstual untuk meningkatkan pemahaman konsep matematika siswa telah dilaksanakan dan untuk mengetahui aktivitas siswa selama proses pembelajaran.

Observasi dalam penelitian ini untuk mengamati aktivitas guru (peneliti) meliputi:

1) Kegiatan Awal

2) Kegiatan Inti

3) Kegiatan Akhir

Lembar-lembar observasi ini selanjutnya digunakan sebagai data observasi.

\section{Teknik Analisis Data}

Analisis data dalam penelitian ini dilakukan dalam beberapa tahap,yaitu :

\section{Reduksi Data}

Data penelitian yang telah terkumpul baik melalui tes dan observasi kemudian ditelaah oleh peneliti dan guru. Data tersebut ditelaah secara menyeluruh sejak awal dan dikumpulkan sampai seluruh data penelitian terkumpul. Reduksi data dilakukan setelah data terkumpul.Kegiatan reduksi berupa pengkategorian dan pengklasifikasian data. Setelah diklasifikasikan, data dikelompokkan kemudian dilanjutkan pada penyimpulan .Kegiatan reduksi ini bertujuan untuk melihat kesalahan jawaban siswa dalam menyelesaikan soal-soal tentang materi bangun ruang sisi lengkung.

\section{Interpretasi hasil}

Yuli Ragelia Sinaga, Nurliani Manurung, 2015. Penerapan Model Pembelajaran Berbasis Masalah (PBM) untuk Meningkatkan Kemampuan Pemahaman Konsep Matematika pada Materi Pecahan Siswa Kelas VII. Inspiratif. Vol. 1 No. 1, hal 75-82 


\section{Pencapaian Pemahaman Konsep Siswa}

Berdasarkan hasil analisis terhadap kegiatan belajar,maka dapat diperoleh tingkat kemampuan pemahaman konsep peserta didik. Data tentang hasil belajar (kognitif) siswa dikonversikan menjadi Nilai Persentasi dengan dengan menggunakan rumus :

$\mathrm{NP}=\frac{\text { jumlah jawaban yang benar }}{\text { jumlah skor maksimal }} \times 100 \%$

Kemudian untuk mengetahui nilai rata-rata siswa digunakan rumus :

$$
\bar{X}=\frac{\sum X_{i}}{N}
$$

(Sudjana, 2009:67)

Keterangan :

$$
\begin{array}{ll}
\sum_{N} X_{i} & =\text { jumlah nilai siswa } \\
& =\text { jumlah sampel }
\end{array}
$$

Menghitung Tingkat Pemahaman

Konsep Siswa

Kategori pemahaman siswa adalah sebagai berikut (Sudjana, 2009:126) :

\section{Tabel 2.1. Tingkat Pemahaman Siswa}

\begin{tabular}{|c|c|}
\hline Tingkat Pemahaman & Kriteria \\
\hline $90 \%-100 \%$ & Sangat tinggi \\
$80 \%-89 \%$ & Tinggi \\
$65 \%-79 \%$ & Sedang \\
$55 \%-64 \%$ & Rendah \\
$0 \%-54 \%$ & Sangat Rendah \\
\hline
\end{tabular}

\section{Analisis Hasil Observasi}

Dari hasil observasi yang telah dilakukan peneliti, dilakukan penganalisaan dengan menggunakan rumus :

$$
\mathrm{P}_{\mathrm{i}}=\frac{\text { Jumlah skor seluruh aspek yang dinilai }}{\text { Banyak aspek yang dinilai }}
$$

Keterangan :

$$
\mathrm{P}_{\mathrm{i}}=\text { hasil pengamatan pada }
$$

pertemuan ke-i
Adapun kriteria rata-rata penilaian observasi yaitu :

$0-1,1$ : sangat buruk

$1,2-2,1$ : kurang baik

$2,2-3,1$ : baik

$3,2-4,0$ : sangat baik

\section{Menarik Kesimpulan}

Setelah data diperoleh dan dianalisis maka ditarik kesimpulan berkenaan dengan hasil penelitian yang dilakukan,yaitu bagaimana penerapan model pembelajaran berbasis masalah (PBM) dapat meningkatkan pemahaman konsep matematika siswa di kelas VII SMP Swasta Istiqlal Delitua Tahun Ajaran 2013/2014. Penarikan kesimpulan ini tentang peningkatan atau perubahan yang terjadi dilakukan secara bertahap dari kesimpulan sementara yang ditarik pada akhir siklus I ke kesimpulan pada akhir siklus II dan seterusnya.Kesimpulan pertama sampai dengan yang terkhir saling terkait dimana kesimpulan pertama sebagai pijakan.

Tolak ukur keberhasilan pada penelitian ini adalah apabila rata-rata pemahaman konsep matematika siswa pada materi pecahan di kelas VII SMP Swasta Istiqlal Delitua Tahun Ajaran 2014/2015 meningkat dengan kriteria minimal sedang. Pemahaman konsep matematika siswa dikatakan meningkat apabila rata-rata pemahaman konsep matematika siswa pada siklus II lebih tinggi dibanding siklus I.

Nilai rata-rata siswa dihitung pada setiap tes yang diberikan untuk melihat ada tidaknya peningkatan nilai antara tes pemahaman konsep (siklus I) dengan tes pemahaman konsep (siklus II).

\section{HASIL DAN PEMBAHASAN}

Berdasarkan hasil tes pemahaman konsep yang diberikan kepada siswa diperoleh bahwa kemampuan siswa dalam memperoleh pemahaman pecahan mengalami peningkatan. Dari hasil analisis yang telah dilakukan, diperoleh bahwa

Yuli Ragelia Sinaga, Nurliani Manurung, 2015. Penerapan Model Pembelajaran Berbasis Masalah (PBM) untuk Meningkatkan Kemampuan Pemahaman Konsep Matematika pada Materi Pecahan Siswa Kelas VII. Inspiratif. Vol. 1 No. 1, hal 75-82 
peneliti sudah mampu meningkatkan proses pembelajaran dengan menerapkan model Pembelajaran Berbasis Masalah. Hal ini didasarkan pada hasil tes pemahaman konsep siklus I dan II, kemampuan siswa dalam menyelesaikan soal-soal pemahaman konsep mengalami peningkatan. Hasil ini dapat dilihat dari:

1. Peningkatan nilai rata-rata kelas yang diperoleh siswa.

Nilai rata-rata kelas pada tes pemahaman konsep siklus I sebesar 63,85 dan meningkat menjadi 81,69 pada siklus II sehingga diperoleh peningkatan rata-rata pemahaman konsep siswa sebesar 17,84. Lebih jelasnya dapat dilihat pada diagram dibawah ini:

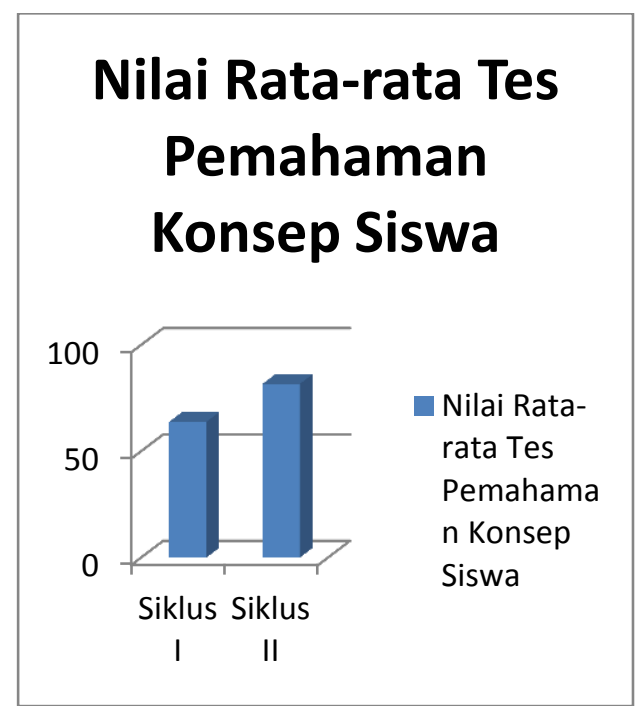

Gambar 4.1 Diagram nilai rata-rata tes pemahaman konsep siswa

2. Peningkatan jumlah siswa yang mencapai ketuntasan belajar dalam menyelesaikan soal-soal tes pemahaman konsep.

Pada siklus I diperoleh 19 siswa atau $57,57 \%$ siswa mencapai ketuntasan belajar, sedangkan pada siklus II diperoleh 30 siswa atau 90,9\% siswa mencapai ketuntasan belajar. Peningkatan jumlah siswa mencapai ketuntasan belajar sebanyak 11 siswa atau 33,33\%. Lebih rinci dapat dilihat pada gambar diagram berikut ini:

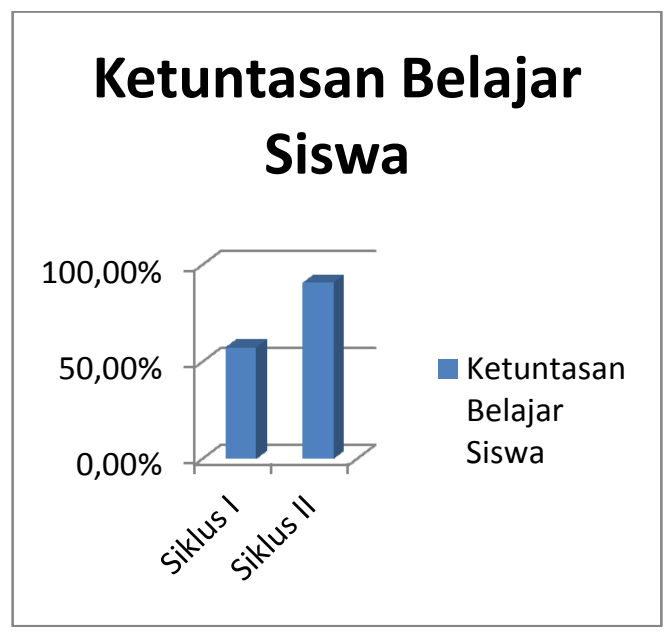

Gambar 4.2 Diagram Ketuntasan Belajar Siswa

3. Peningkatan tingkat pemahaman konsep siswa.

Pada siklus II tingkat pemahaman konsep siswa mengalami peningkatan dari siklus I, dari 33 siswa terdapat 2 siswa yang memperoleh nilai antara 90-100 dikategorikan siswa dengan kemampuan sangat tinggi, 5 siswa memperoleh nilai antara 80-89 dikategorikan siswa dengan kemampuan tinggi, 23 siswa memperoleh nilai antara 65-79 dikategorikan siswa dengan kemampuan sedang, dan 3 siswa memperoleh nilai antara 55-64 dikategorikan siswa dengan kemampuan rendah. Tingkat kemampuan konsep siswa meningkat pada siklus II dari 33 siswa terdapat 5 siswa yang memperoleh nilai antara 90-100 dikategorikan siswa dengan kemampuan sangat tinggi, 21 siswa memperoleh nilai antara 80-89 dikategorikan siswa dengan kemampuan tinggi, 4 siswa memperoleh nilai antara 65-79 dikategorikan siswa dengan kemampuan sedang dan 3 siswa

Yuli Ragelia Sinaga, Nurliani Manurung, 2015. Penerapan Model Pembelajaran Berbasis Masalah (PBM) untuk Meningkatkan Kemampuan Pemahaman Konsep Matematika pada Materi Pecahan Siswa Kelas VII. Inspiratif. Vol. 1 No. 1, hal 75-82 
lainnya memperoleh nilai antara 55-64 dikategorikan siswa dengan kemampuan rendah.

Berdasarkan hasil penelitian yang telah dilakukan, dengan menggunakan Gain Skore maka diperoleh peningkatan pemahaman konsep siswa dari siklus I sampai siklus II adalah sebagai berikut:

Gain Skore $=\frac{\text { Skor postest }- \text { skor pretest }}{\text { skor maksimum }- \text { skor pretest }}$

Gain Skore $=\frac{81,69-63,85}{100-63,85}=0,49$

Peningkatan pemahaman konsep siswa berdasarkan gain skore adalah 0,49 yaitu dalam kategori sedang.

Berdasarkan hasil penelitian yang diperoleh bahwa model Pembelajaran Berbasis Masalah dapat meningkatkan pemahaman konsep pecahan pada siswa kelas VII SMP Swasta Istiqlal Delitua. Peningkatkan pemahaman konsep siswa terlihat dari peningkatan nilai rata-rata, peningkatan persentase ketuntasan belajar individu dan ketuntasan belajar klasikal. Setelah melihat hasil penelitian ini, dapat dikatakan bahwa penerapan model Pembelajaran Berbasis Masalah (PBM) salah satu upaya konkrit yang dapat meningkatkan pemahaman konsep siswa.

Dalam melaksanakan penelitian ini, terdapat kelemahan yang ditemukan peneliti sehingga model Pembelajaran Berbasis Masalah ini tidak menjadikan seluruh siswa memperoleh nilai yang tinggi atau sangat tinggi. Adapun kelemahan peneliti adalah selama pelajaran berlangsung diantaranya sulitnya mengelola kelas pada pertemuan awal dengan langkahlangkah pembelajaran yang dirancang pada pembelajaran berbasis masalah (PBM) karena masih baru bagi subjek. Dalam hal menganalisis data, peneliti hanya melihat apakah terjadi peningkatan nilai rata-rata dan persentase ketuntasan belajar. Peneliti tidak memperhatikan apakah peningkatan tersebut signifikan dari tiap siklus. Pengukuran tes hasil belajar hanya sebatas aspek kognitif saja, sedangkan aspek psikomotor dan aspek yang lainnya tidak ikut diukur.

\section{KESIMPULAN}

Berdasarkan hasil penelitian dan pembahasan diperoleh kesimpulan sebagai berikut: Setelah penerapan model pembelajaran berbasis masalah (PBM) dapat meningkatkan pemahaman konsep matematika siswa kelas VII SMP Swasta Istiqlal Delitua Tahun Ajaran 2014/2015 dilihat dari nilai rata-rata siswa pada siklus I sebesar 63,85 dan meningkat pada siklus II menjadi 81,69 sehingga diperoleh peningkatan rata-rata pemahaman konsep siswa sebesar 17,84. Setelah penerapan model pembelajaran berbasis masalah (PBM) dapat meningkatkan hasil belajar siswa kelas VII SMP Swasta Istiqlal Delitua Tahun Ajaran 2014/2015 dilihat dari peningkatan ketuntasan belajar sebanyak 11 siswa $(33,33 \%)$ yaitu dari 19 siswa $(57,57 \%)$ pada siklus I meningkat menjadi 30 siswa $(90,9 \%)$ dan sudah mencukupi syarat ketuntasan klasikal yaitu $\geq 75 \%$ siswa yang mencapai tes kemampuan pemahaman konsep $\geq 65$. Pembelajaran yang dilakukan termasuk ke dalam kategori sangat baik $(3,5)$ dengan peningkatan nilai observasi sebesar 0,35 $(3,5-3,15)$ dari siklus I ke siklus II.

\section{REFERENSI}

Amir, M.T. 2009. Inovasi Pendidkan Melalui Problem Based Learning. Jakarta: Kencana

Arends, R. I. 1997. Class Room Instruction and Management. New York: MC Grow-Hill Componies, Inc.

Arikunto, S. 2008. Dasar-dasar Evaluasi Pendidikan (Edisi Revisi). Jakarta: Bumi Aksara

Dahar, R. W. 2011. Teori-teori Belajar dan Pembelajaran. Bandung: Erlangga

Yuli Ragelia Sinaga, Nurliani Manurung, 2015. Penerapan Model Pembelajaran Berbasis Masalah (PBM) untuk Meningkatkan Kemampuan Pemahaman Konsep Matematika pada Materi Pecahan Siswa Kelas VII. Inspiratif. Vol. 1 No. 1, hal 75-82 
Dimyati dan Mudjiono. 2009. Belajar dan Pembelajaran. Jakarta: Rineka Cipta.

Djamarah, S. B. 2011. Psikologi Penelitian. Jakarta: Rineka Cipta

Hamalik, O. 2004. Proses Belajar Mengajar.Jakarta: Bumi Aksara

Hudojo, H. 2005. Pengembangan Kurikulum dan Pembelajaran Matematika. Malang: UM Press

Indrawati, Y. 2006. Faktor-faktor yang Mempengaruhi Kinerja Guru Matematika dalam Pelaksanaan KBK pada SMA Kota Palembang, Jurnal Manajemen \& Bisnis Sriwijaya Vol 4, No \& Juni 2006

Kementrian Pendidikan dan Kebudayaan. 2013. Matematika SMP/MTs Kelas VII. Jakarta: Politeknik Negeri Media Kreatif

Kementrian Pendidikan dan Kebudayaan. 2014. Matematika SMP/MTs Kelas VII Semester 1 Edisi Revisi. Jakarta: Pusat Kurikulum dan Perbukuan

Maryunis, A. 1989. Metode Pemetaan Informasi dalam Proses Belajar Mengajar Matematematika. Jakarta: Pascasarjana IKIP Jakarta

Muijs, D dan Reynolds. 2008. Effective Teaching Teori dan Aplikasi Edisi Kedua. Yogyakarta: Pustaka Pelajar

Purwanto. 2011. Evaluasi Hasil Belajar. Yogyakarta: Pustaka Pelajar.

Riyanto, Y. 2009. Paradigma Baru Pembelajaran: Sebagai Refrensi Bagi Guru/Pendidik dalam Implementasi Pembelajaran yang Efektif dan Berkualitas. Jakarta: Kencana

Sagala, S. 2009. Konsep dan Makna Pembelajaran. Bandung: Alfabeta

Sanjaya, W. 2011. Strategi Pembelajaran Berorientasi Standar Proses Pendidikan. Jakarta: Kencana
Slameto. 2003. Belajar dan Faktor-faktor Yang Mempengaruhinya. Jakarta: Rineka Cipta

Sudjana, N. 2009. Penilaian Hasil Belajar Mengajar. Bandung: PT Remaja Rosdakarya.

Suherman, E. 1990. Evaluasi Pendidikan Matematika. Bandung: Wijaya Kesuma

Suparno, P. 2001. Teori Perkembangan Kognitif Jean Piaget. Yogyakarta: Karnius

Sutirman. 2013. Media dan Model-Model Pembelajaran Inovatif. Yogyakarta: Graha Ilmu

Syah. M. 2010. Psikologi Pendidikan dengan Pendekatan Baru. Bandung: Remaja Rosdakarya.

Tim Pelatih Proyek PGSM. 1999. Penelitian Tindakan Kelas. Departemen Pendidikan dan Kebudayaan Direktorat Jenderal Pendidikan Tinggi Proyek Pengembangan Guru Sekolah Menengah

Trianto. 2011. Mendesain Model Pembelajaran Inovatif-Progresif. Jakarta: Kencana

Wena, M. 2011. Strategi Pembelajaran Inovatif Kontemporer. Jakarta: Bumi aksara

Winkel, W.S. 2007. Psikologi Pendidikan. Jakarta: P.T. Grasindo

Yamin, M. 2013. Strategi \& Metode dalam Model Pembelajaran. Jakarta: GP Press Group

Yuli Ragelia Sinaga, Nurliani Manurung, 2015. Penerapan Model Pembelajaran Berbasis Masalah (PBM) untuk Meningkatkan Kemampuan Pemahaman Konsep Matematika pada Materi Pecahan Siswa Kelas VII. Inspiratif. Vol. 1 No. 1, hal 75-82 